\title{
Variability of growth, maturation and fecundity of gibel carp (carassius gibelio) in different environments of Uzbekistan
}

\author{
$B$ Kamilov $^{1, *}, M$ Yuldashov $^{1}, U$ Soatov $^{1}$, and $M$ Nazarov $^{2}$ \\ ${ }^{1}$ Tashkent State Agrarian University, University str., 2, Tashkent province, 100140 Uzbekistan \\ ${ }^{2}$ Ferghana State University, Murabbiylar str., 19, Ferghana, 150100 Uzbekistan
}

\begin{abstract}
The goal of present study was to examine gibel carp, Carassius gibelio (Bloch, 1782) growth, maturation, fecundity and ripe eggs size under pond fish culture conditions and conditions of natural water bodies of the River Syrdarya, Uzbekistan. Gibel carp originally came from the River Amur (Russia), it was introduced to Uzbekistan in 1950s. Recently, it is wide spread species in local ichthyofauna. Females matured for the first time at age 2 years: in ponds in $8-10 \mathrm{~cm}$ in standard length, in the river in $18-20 \mathrm{~cm}$. The GSI increased to spawning up to $2.9-25 \%$. In fish farm ponds absolute fecundity was 1,4 - 51,300 eggs, in the River Syrdarya $9,2-91,400$ eggs. Relative fecundity in all populations was $21-590$ eggs/g in weight of gutted fish. In April, there were two peaks of ripe and yolk eggs size: 1 st $-0.89-1.69 \mathrm{~mm}, 2 \mathrm{nd}-0.69-0.9 \mathrm{~mm}$.
\end{abstract}

\section{Page layout}

Biological invasions are now considered as one of the most major issues causing threats to the conservation of biodiversity. The most, introduced species fail to establish new population. However, the introduction of a non-native species into a novel ecosystem is likely to create an ecological impact if the species is able to successfully establish a selfreproducing population. The establishment success of an introduced species highly depends on its intrinsic ecological and biological characteristics (e.g. reproduction guild, fecundity, dietary breadth) $[1,5,8,9]$. One such invasive species is gibel carp, Carassius gibelio (Bloch, 1782), in which populations introduced to Eurasia from Far Eastern Asia in the 17th century; increase and spread of this species have been reported in many areas including Russia, Ukraine, Turkey, the Danube River Basin, rivers of the Baltic Sea basin in Europe [2, 3, 10, 12].

The gibel carp from the River Amur (Russia) was introduced to 'Savino' pond fish farm (Moscow province, Russia), from which, in the late 1950s, it was introduced for aquaculture purposes to 'Damaschy' and 'Balikchy' fish farms in Tashkent province, Uzbekistan $[11,14,16]$. In 1960s, more promising and productive polyculture of common carp (Cyprinus carpio) and Chinese carps technology was developed in the country. Pond conditions of that polyculture became unfavourable for gibel carp, so species came to be

* Corresponding author: bkam58@,rambler.ru 
trash fish. Besides, gibel carp found favourable environments for natural reproduction in channels and ponds fish farms network. Still 1970s, gibel carp was widely spread with cultured carps fish seeds to all fish farms in the Uzbekistan. At the same time, gibel carp easily entered rivers and lakes in vicinities of fish farms. In natural (wild) water bodies (reservoirs, lakes, former riverbed) gibel carp has found favourable environments, riches large body size and has status of commercial species. Recently there are abundant as small trash, so large commercial gibel carps on plane part of Uzbekistan; representatives of both easily entered as aquaculture so wild water bodies.

The gibel carp is a nonmigratory, benthopelagic and omnivore fish in stagnant and slow running waters. Gibel carp is one of the most common and widely distributed Cyprinid species in ponds, lakes, reservoirs and rivers in plane part of Uzbekistan $[4,6,7,19]$.

In Uzbekistan, up to middle 1970s, as wild so stocks in fish farms were monosexual (only females) [11, 13]. In 1990s rate female to males was 7:3 in average $[15,19]$. Gibel carp sexual and gynogenetic reproduction and vast ecological tolerance including its resistance to unfavourable conditions have resulted in the becoming the most successful invasive fish form in the waters of Uzbekistan and other countries of Central Asia [16, 17]. The study of age, growth, maturation and fecundity is essential in fisheries and aquaculture. Estimating of those characteristics of gibel carp in natural water bodies and aquaculture in local conditions is limited and fragmental. The aim of the present study was point out the growth and reproduction of the gibel carp population in wild (Syrdarya River) and cultured (fish farms ponds) environments in Uzbekistan.

\section{Materials and methods}

\subsection{Study site}

'Balyktchy' fish farm is situated in the vicinity of Tashkent, nearly $40^{\circ} 53^{\prime}$ north and $168^{\circ} 45^{\prime}$ east, on the bank of the River Syrdarya in the middle stream; the total area of ponds is 2,500 ha. 'Besharik' fish farm is situated in Fergana Valley and has about 700 ha of ponds, 'Surkhandarya' fish farm is on the bank of the Surkhandarya River (the basin of the Amudarya River) and has about 120 ha of ponds (Fig. 1).

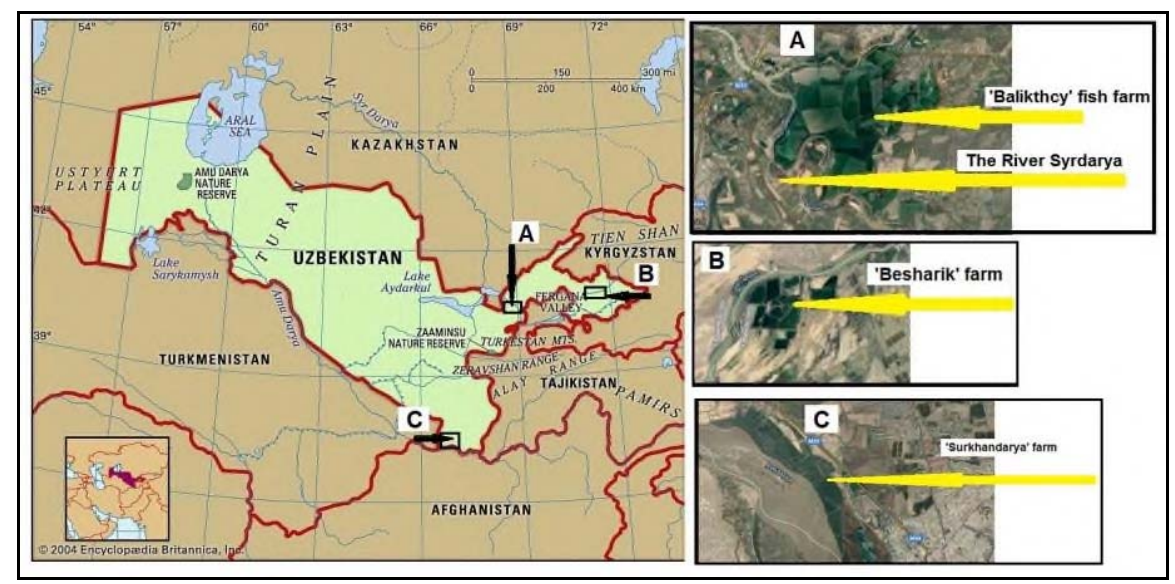

Fig. 1. Uzbekistan map and study sizes: A - 'Baliktchy' fish farm and the River Syrdarya; B 'Besharik' fish farm,: C - 'Surkhandarya' fish farm (the River Amudarya). 
The climate is extremely continental, arid. The lowest average monthly temperature is in January at $-1--2.1^{\circ} \mathrm{C}$; during some winters, ice cover ponds and lakes $10-15 \mathrm{~cm}$ for about 1-1.5 months. The highest average monthly temperature is in July at $27-29.1^{\circ} \mathrm{C}$; in daytime often air temperature may be $35-40^{\circ} \mathrm{C}$. Water in the ponds may reach $29-31^{\circ} \mathrm{C}$ in the daytime. In Tashkent province, the annual precipitation of $185-193 \mathrm{~mm}$ falls mainly in November-May [18, 20].

In fish farms, pond silver carp, Hypophthalmichthys molitrix, are stocked together with common carp, bighead carp, Hypophthalmichthys nobilis, and grass carp, Ctenopharyngodon idella; the following stocking density is used for fry 15,000-20,000 individuals per ha (in first year of fish culture), yearlings 3,000 individuals per ha (in 2nd year of table fish culture).

\subsection{Sample collection and analyses}

Gibel carp samples were collected each month from October 2018 to October 2019 from the River Syrdarya (including lakes, former riverbed) by using gill nets with 14, 16, 24, 32, $36,40,50,60 \mathrm{~mm}$ in mesh size in the river. In ponds samples were collected at the same time by using dragnet with $4,8,10,14,18,24,32,40 \mathrm{~mm}$ in mesh size.

Morphological identification and systematic status of gibel carp were made, using characters given by $[17,19,21]$. The standard length (SL) without caudal fin (to the end of scale coverlet) in the nearest $1 \mathrm{~mm}$ and body weight (W) in the nearest $1 \mathrm{~g}$ were recorded for each fish [22].

Scales (3-4 samples) were taken from 1st row above lateral line under 1st ray of dorsal fin. Scales were cleaned in water and examined under binocular microscope for the age determination. Scales were measured with the aid of a microfiche under magnification 10.0x. Annual measurements were taken along diagonal between lateral and front sectors (Fig. 2).

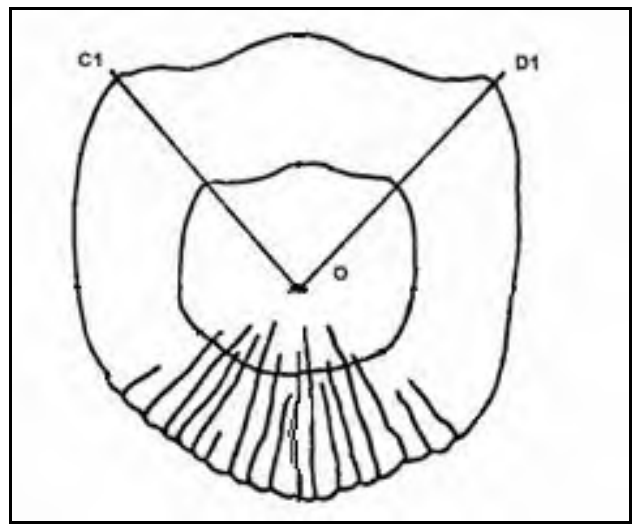

Fig. 2. Gibel carp scale chart and transects of measuring: $\mathrm{C} 1 \mathrm{O}$ and $\mathrm{D} 1 \mathrm{O}$ - diagonal between lateral and front sectors.

Tissue samples of gonads were fixed in Bouin's solution; paraffin wax sections of 5-7 $\mu \mathrm{m}$ were stained in hematoxilin. Ovarian development was classified into six stages according to $[14,23]$. Gonad weight (q) was determined for females at stage IV in the nearest $0.1 \mathrm{~g}$. Individual absolute fecundity (AF) was recorded for fish caught in April and early May as the number of eggs which were soon to be spawned. Individual relative fecundity (RF) was calculated as $\mathrm{RF}=$ eggs/body weight of the gutted fish. Female ripe egg size was calculated as average of 100 egg diameter measurement. Correlation and 
regression analyses were done to describe fecundity equations; statistical significance was tested to $\mathrm{p}<0.05$.

\section{Results}

A total 336 specimen of gibel carp were sampled. Overall sex ratio between females and males were 6-8 to one in fish farms and 3-4:1 in river. The ages, total lengths and weights of the samples from all water bodies studied ranged between 1 to 3 years, 8.0 to $28.0 \mathrm{~cm}$ and 16 to $520 \mathrm{~g}$, respectively.

Gilber carp size in samples were: $2.0-13.4 \mathrm{~cm}$ in standard length and $2.6-84.0 \mathrm{~g}$ in weight in 'Besharik' fish farm; $2.8-11.0 \mathrm{~cm}, 3.2-36.5 \mathrm{~g}$ - in 'Surkhandarya' fish farm, $3.6-21.1 \mathrm{~cm}, 6.5-11 \mathrm{~g}$ - in 'Balyktchy' fish farm; $10.1-28.0 \mathrm{~cm}, 19-520 \mathrm{~g}$ - in the River Syrdarya.

Scale of gibel carp is cycloid with flat edges. Gibel carp belongs to fishes with large scale; there were $28-34$ scales in lateral line in our samples.

During the colder months the sclerites are crowded together on scales; during the warmer months sclerites are spaced further apart (wide to each other). Annuli (true year mark) are characterized by crowded sclerites. Rather often false rings can be found on scales as a result of different unusual events (with growth stop) during vegetation season. False ring are thin, open-ended, visible not around the whole scale, situated in zone of apart sclerites.

Annuli on scale of immature gibel carp appear in the late February - March and of matured fish appear in the late April - Early May (after spawning occurs in second half of April - early May). Standard length - scale size relationship had strong positive significant correlation for diagonal between lateral and front sector $(\mathrm{r}=0.98)$; annuli on that radius were visible more distinctly for us. That's why, we have used that diagonal for backcalculation of growth rate by using Fraiser-Lee's modification of direct proportional method [6].

In the first year, gonads of both sexes developed fast; in the summer, all summerlings (at age $0+$ ) had gonads at stage I, they were juvenile. The gonads weighed a few $\mathrm{mg}$ and they appeared as colorless to translucent - brown thin threads; histologically, nests of oogonia and a few pre-vitellogenetic oocytes were visible. During the first year when fish reach standard length 5-6 $\mathrm{cm}$ in ponds and $7-8 \mathrm{~cm}$ in river, gonads came to stage II. Usually that happened in second part of August - September. After September, sex and stage II could be defined visually for all summerling samples; histologically, increasing number of advanced pre-vitellogenetic oocytes were evident in addition to oogonia. The largest oocytes ranged from 71 to 149 (mean 102) $\mu \mathrm{m}$ in diameter; the ovarian weight increased to $0.3-1.2$ (mean 0.7 ) g.

In Spring after wintering, all 1-year-old females had ovaries at stage II, but gonads were rather developed. Pre-vitellogenetic oocytes increased size noticeably; the larger oocytes ranged from 94 to 204 (mean 109) $\mu \mathrm{m}$ in diameter. The ovarian weight increased to $1.0-$ 2.1 (mean 1.4) g.

In samples of gibel carp at age 1+ collected in Autumn (during the second year of their life), all females had gonads at stage III. Fish had opaque or brownish-green ovaries with oocytes visible to the naked eye. Histologically, vitellogenetic oocytes were seen in addition to pre-vitellogenetic oocytes and oogonia. Ovarian weight increased to $0.7-12,5$ $\mathrm{g}$; vitellogenetic oocytes had a diameter of $130-602 \mu \mathrm{m}$. That was visible as for gibel carp from fish farm ponds, so from river. At the same time gibel carp from river were noticeably larger (15.6 - $18.9 \mathrm{~cm}$ in standard length) than those from pond fish farm (10.2 $13 \mathrm{~cm}$ in standard length). 
At spring, all 2-year-old females of gibel carp were matured. Eggs $(0.61-1.69 \mathrm{~mm})$ were yolk-laden and clearly visible to the naked eye. Histologically, numerous advanced vitellogenetic oocytes were present plus pre-vitellogenetic oocytes.

So, first maturation of gibel carp was marked at 2-year-old age as in pond fish farms, so in river. In 'Besharik' fish farm maturation was reached by females at $9.1-13.4$ (mean $11.4) \mathrm{cm}$ in standard length and $24.6-84.0(20.4) \mathrm{g}$ in total weight. In 'Surkhandarya' fish farm matured fishes were $8.0-11.0(9.6) \mathrm{cm}$ in length and $16.0-36.5(25.5) \mathrm{g}$ in weight. In 'Baliktchy' fish farms females matured when they reached $10.2-12.2(11.8) \mathrm{cm}$ in length and 18.0 - 20.0 (19.1) $\mathrm{g}$ in weight. At the same, time gibel carp females in the River Syrdarya matured for the first time at 2-years-old age when they reached $18-22.2$ (19.1) $\mathrm{cm}$ in total length and $101-301.5$ (200.4) $\mathrm{g}$ in body weight.

In the first year gonads developed rather fast, and the GSI of 1-year-old females reached $0.01-0.02 \%$ in all sites. In the second year ovaries also developed rather fast; in April (just before spawning), the Gonadosomatic index (GSI) of 2-year-old females reached 2.9 - $15.6(8.04+0.44)$ in 'Besharik' fish farm, $6.2-15.9(10.86+0.30)$ in 'Surkhandarya' fish farm, 4.0 - $25.0(15.1+0.51)$ in Baliktchy' fish farm, 6.8 - $23.2(17.1+0.50)$ - in the River Syrdarya.

Weak dependence between GSI and standard body length of firstly matured females was marked for gibel carp in fish farm ponds: $r_{\mathrm{SL}-\mathrm{gsi}}=0.44 ; \mathrm{r}_{\mathrm{W}-\mathrm{gsi}}=0,31$ in 'Besharik' fish farm, $r_{\mathrm{SL}-\mathrm{gsi}}=0.43 ; \mathrm{r}_{\mathrm{W}-\mathrm{gsi}}=0.42-$ in 'Surkhandarya' fish farm, $\mathrm{r}_{\mathrm{SL}-\mathrm{gsi}}=0.41 ; \mathrm{r}_{\mathrm{W}-\mathrm{gsi}}=0.35-$ in 'Baliktchy' fish farm. At the same time GSI varied indendently in the River Syrdarya $\left(\mathrm{r}_{\mathrm{SL}-\mathrm{gsi}}=0.14 ; \mathrm{r}_{\mathrm{W}-\mathrm{gsi}}=0.23\right)$.

Gibel carp spawning began in the late April - early May when water temperature reached $16-18^{\circ} \mathrm{C}$. Gibel carp used flooded grasses or submerged aquatic macrophytes at a depth of $0.25-1.5 \mathrm{~m}$ as a spawning substrate. Intermittent (twice) spawning was determined. Second spawning occurred in late July - August.

In the Spring, matured 2-year-old and 3-year-old females had gonads at stage IV with gonad weight $0.8-8.8(3.59+0.33) \mathrm{g}$ in 'Besharik' fish farm; $1.0-4.7(2.35+0.09) \mathrm{g}-$ in 'Surkhandarya' fish farm. In both fish farms strong positive correlation between gonad weight and fish body size was determined: : $\mathrm{r}_{\mathrm{SL}-\mathrm{q}}=0,91 ; \mathrm{r}_{\mathrm{W}-\mathrm{q}}=0,89$ in 'Besharik' fish farm and $\mathrm{r}_{\mathrm{SL}-\mathrm{q}}=0.77 ; \mathrm{r}_{\mathrm{W}-\mathrm{q}}=0.79-$ in 'Surkhandarya' fish farm.

In 'Besharik' fish farm, gibel carp female absolute fecundity varied 2, $370-23,400$ $(10,790+980)$ eggs. Larger females had significantly higher absolute fecundity $\left(\mathrm{r}_{\mathrm{SL}-a f}=\right.$ $\left.0.87 ; \quad r_{W-a f}=0.86\right)$. In 'Surkhandarya' fish farm absolute fecundity varied 1,400-6,270 $(3,470+148)$ eggs. Variability of fecundity was lower than in previous fish farm; nevertheless, positive relationship between absolute fecundity and fish body size in farm was observed ( $\left.\mathrm{r}_{\mathrm{SL}-\mathrm{af}}=0.65 ; \mathrm{r}_{\mathrm{W}-\mathrm{af}}=0.65\right)$.

Gibel carp female absolute fecundity in 'Baliktchy' fish farm was 3,000 - 51,000 $(24,500+215)$ eggs. In fish farm the absolute fecundity strongly correlated with body size: $\mathrm{r}_{\mathrm{SL}-\mathrm{af}}=0.95 ; \mathrm{r}_{\mathrm{W}-\mathrm{af}}=0.89$. We can note, that in 'Baliktchy' fish farm, there were females at ages from $0+$ up to age 3-years in compare with 'Besharik' and 'Surkhandarya' farms where fish at ages 0+ - 2-years were presented. That depends with functions of farms. 'Besharik' and 'Surkhandarya' farms are not full cycle farms; they have only fattening ponds to rise yearlings to table fish (to age 1+). Every year in Autumn, each fattening pond is totally drained, and all fishes are captured. 'Baliktchy' is full cycle farm; it has huge hatchery and fattening ponds for broodstocks of cultured cyprinids including wintering of 1 - 5-year-old generations. So, 3-year-old gibel carp can stay in ponds. Larger gibel carps are commercial fishes and are completely removed from ponds by dragnets.

In water bodies of the River Syrdarya, gibel carp female were more fecund measured as $9,200-91,400(46,120+395)$ eggs. In that population absolute fecundity had positive relationship with body size ( $\left.\mathrm{r}_{\mathrm{SL}-\mathrm{af}}=0.53\right)$. 
Relative fecundity of females from 'Besharik' fish farm varied 85.4 - $540.2(249.5+$ 14.7) eggs/g of gutted fish. Characteristic varied independently from body size $\left(\mathrm{r}_{\mathrm{SL}-\mathrm{rf}}=\right.$ 0,$\left.29 ; r_{\mathrm{W}-\mathrm{rf}}=0,19\right)$; at the same time, there was positive correlation in that stock between GSI and relative fecundity $\left(r_{\text {gsi-rf }}=0.91\right)$ and absolute and relative fecundity $\left(r_{\text {af-rf }}=0.63\right)$.

Relative fecundity of females from 'Surkhandarya' fish farm varied 91.4 - 259.3 (160.9 $+5.4)$ eggs/g of gutted fish. Characteristic varied independently from body size $\left(\mathrm{r}_{\mathrm{SL}-\mathrm{rf}}=\right.$ 0,$\left.24 ; r_{\mathrm{W}-\mathrm{rf}}=0.23\right)$; at the same time, there was positive correlation in that stock between GSI and relative fecundity $\left(r_{\text {gsi-rf }}=0.85\right)$ and absolute and relative fecundity $\left(r_{\text {af-rf }}=0.80\right)$.

Relative fecundity of females in 'Baliktchy' fish farm varied 151.2 - 501.4 (280.1 + $39.2)$ eggs/g of gutted fish. Characteristic varied independently from body size $\left(\mathrm{r}_{\mathrm{SL}-\mathrm{rf}}=\right.$ $\left.0.21 ; r_{\mathrm{W}-\mathrm{rf}}=0.20\right)$; there was positive correlation in that stock between GSI and relative fecundity $\left(\mathrm{r}_{\mathrm{gsi}-\mathrm{rf}}=0.91\right)$ and absolute and relative fecundity $\left(\mathrm{r}_{\mathrm{af}-\mathrm{rf}}=0.85\right)$.

In the River Syrdarya relative fecundity of females was $21.0-590.1(190+27.8)$ eggs/g. Analyses showed that there was no significant relationship between relative fecundity and body size $\left(r_{\mathrm{SL}-\mathrm{rf}}=0.19 ; \mathrm{r}_{\mathrm{W}-\mathrm{rf}}=0.15\right)$; there was positive correlation in that stock between GSI and relative fecundity $\left(r_{\text {gsi-rf }}=0.84\right)$ and absolute and relative fecundity $\left(\mathrm{r}_{\mathrm{af}-\mathrm{rf}}=0.81\right)$.

Ripe eggs size. In Spring, in 'Besharik' fish farm only one size group of ripe eggs were visible on the individual histograms of yolk oocytes; no any portions were observed. Diameter of ripe eggs was $1.50-1.69(1.65+0.04) \mathrm{mm}$ and varied independently from female body size $\left(r_{\text {SL-d }}=-0,14 ; r_{W-d}=-0,09\right)$.

In 'Surkhandarya' fish farm two peaks were observed; there were two groups, significantly differed by t-test. Diameter of larger ripe eggs (which were ready for spawning in May) was $00.88-1.18(1.00+0.006) \mathrm{mm}$; diameter of smaller yolk oocytes was $0.61-0.92(0.74+0.008) \mathrm{mm}$. Both diameters varied independently from female body $\operatorname{size}\left(\mathrm{r}_{\mathrm{SL}-\mathrm{d} 1}=0.22 ; \mathrm{r}_{\mathrm{W}-\mathrm{d} 1}=0.23 ; \mathrm{r}_{\mathrm{SL}-\mathrm{d} 2}=-0.12 ; \mathrm{r}_{\mathrm{W}-\mathrm{d} 2}=0.14\right)$.

Also two peaks were determined for gibel carp in 'Baliktchy' fish farm; diameter of larger ripe eggs (which were ready for spawning in May) was $0.98-1.48(1.40+0.01)$ $\mathrm{mm}$; diameter of smaller yolk oocytes was $0.60-0.90(0.70+0.008) \mathrm{mm}$. Both diameters varied independently from female body size $\left(r_{\mathrm{SL}-\mathrm{d} 1}=0.09 ; \mathrm{r}_{\mathrm{W}-\mathrm{d} 1}=0.07 ; \mathrm{r}_{\mathrm{SL}-\mathrm{d} 2}=0.20 ; \mathrm{r}_{\mathrm{W}-}\right.$ $\mathrm{d} 2=0.10)$.

Also two peaks of ripe egg size were marked for the gibel carp from the River Syrdarya. Diameter of larger ripe eggs (which were ready for spawning in May) was $1.01-1.5$ (1.40 $+0.01) \mathrm{mm}$; diameter of smaller yolk oocytes was $0.61-0.83(0.65+0.007) \mathrm{mm}$. Both diameters varied independently from female body size $\left(\mathrm{r}_{\mathrm{SL}-\mathrm{d} 1}=0.11 ; \mathrm{r}_{\mathrm{W}-\mathrm{d} 1}=0.14 ; \mathrm{r}_{\mathrm{SL}-\mathrm{d} 2}=\right.$ $\left.0.19 ; \mathrm{r}_{\mathrm{W}-\mathrm{d} 2}=0.16\right)$.

\section{Discussion and conclusions}

Gibel carp is able to expand its range of distribution by having ecological plasticity, and a high tolerance for unfavourable environmental conditions. Growth and reproduction, which usually indicated as principal factor of invasion success of gibel carp could be reason for its strong establishment of new populations $[12,20]$. Both characteristics variability in gibel carp populations is strong; variability is observed even within the same country, even in the same vicinity. Remarkably lower growth of gibel carp in fish farm ponds can be explained by high pressure of technological methods favourable for cultured carps but unfavourable for gibel carp.

Our data showed that Uzbekistan environments are favourable for gibel carp. In natural water bodies like in the River Syrdarya populations inhabit in completely wild conditions. In aquaculture fish farms gibel carp is unwanted, trash fish. Farmers use permits, dewatering of ponds. Total catch of gibel carp by dragnets reduces its quantity. But the 
absolute removal of this fish by such methods in big ponds $(10-100$ ha) is impossible. Gibel carp inhabits in farm channel network and enters fattening ponds every year after their filling with water in spring.

In Uzbekistan, in fish farms prussian carp growth rate was back-calculated as $\mathrm{SL}_{1}=6.8-$ $8.9 \mathrm{~cm} ; \mathrm{SL}_{2}=10.2-12.3 \mathrm{~cm} ; \mathrm{SL}_{3}=13.9-15.1 \mathrm{~cm}$ and in the River Syrdarya $\mathrm{SL}_{1}=10$ $\mathrm{cm} ; \mathrm{SL}_{2}=19.9 ; \mathrm{SL}_{3}=25.7 \mathrm{~cm}$

In local area of gibel carp global distribution, it reaches first maturation in different regions from 1-year-old to 4-year-old age. In area, in the River Amur (Russia), gibel carp (highly commercial fish) reach $18-39 \mathrm{~cm}$, reach first maturation at 4-year-old age [15].

In Turkey, females reach first maturation at age 2-years at $7.1 \mathrm{~cm}$ in standard length; during maturation, GSI increased at most 14.09-25\% in April (just before spawning). Strong positive relationship between GSI and body size in spring was observed in population included 12 age groups $(r=0,74)$. Spawning was observed in April - June. Ripe eggs diameter was marked as $0.98+0.6 \mathrm{~mm}$ in Turkey; egg size was independent from female body size $(\mathrm{r}=0.01)$. Individual absolute fecundity in Turkey was determined $12.9-$ 298.7 (mean 112.4) thousand eggs. Positive relationship with female body size was determined $\left(\mathrm{r}_{\mathrm{SL}-\mathrm{af}}=0.68 ; \mathrm{r}_{\mathrm{SL}-\mathrm{W}}=0.7\right)$. Relative fecundity was calculated as $150-204 \mathrm{eggs} / \mathrm{g}$ $[3,7,12]$.

In Kazakhstan, there are populations in lakes and rivers with first maturation at 3 - and at 4-years-old age. Spawning occurs in May, when water temperature reaches $14^{\circ} \mathrm{C}$. Multiple spawning was determined in that country. Absolute fecundity was marked as $51-345$ thousand eggs [17].

In Uzbekistan, in all populations studied, gibel carp reaches first maturation at an age of 2 years, but in river fish were larger. River females had significantly higher absolute fecundity than in ponds. At the same time, relative fecundity of females and ripe eggs size was closed to pond fish.

In conditions of fish farm ponds in different regions of Uzbekistan, gibel carp females reached first maturation at 2-year-old age in $8-10 \mathrm{~cm}$ in standard length and $16-24 \mathrm{~g}$ in body weight. In natural (wild) environments of the River Syrdarya, gibel carp females reach first maturation also at 2-year-old age in $18-22 \mathrm{~cm}$ and more in standard length and 100 $305 \mathrm{~g}$ and more in body weight.

So, rate of female maturation is the same in environments of plane part of the country (both in wild and aquaculture environments), but growth rate in natural water bodies is significantly higher. Gibel carp in Uzbekistan can be labeled as fast matured in compare with other regions of recent species distribution.

In Uzbekistan, in fish farm ponds absolute fecundity was $1.4-51.3$ thousand eggs, in the River Syrdarya - 9.2 - 91.4 thousand eggs; differences could be related with differences in growth rate (slow growth in fish farms and fast - in natural water bodies). Note, that in both types of broodstock, there are fishes only up to 3-year-old ages, mostly. Larger fish are output from stocks by fishing pressure in rivers and technological methods in fish farms with carps polyculture.

We have noted high variability of gibel carp female relative fecundity for both group: trash gibel carp in fish farm ponds had $91-540$ eggs/g, in the River Syrdarya - 21 - 590 eggs/g. Therefore, in wild populations in Uzbekistan, gibel carp has high growth rate and higher absolute fecundity in compare with trash stocks in fish farms.

\section{References}

1. M. Abramenko, O. Kravchenko, A. Velikoivanenko, Journal of Ichthyology, 37, 56-65 (1997) 
2. A. A. Amanov, Ecology of fishes in south of Uzbekistan and neighboring countries, 161 (FAN press, Tashkent, 1985)

3. İ. Balık, R. Özkök, H. Çubuk, R. Uysal, Turkish Journal of Zoology, 28, 19-28 (2004)

4. S. Blanchet, G. Loot, G. Grenouillet, E. Bross, Ecology of Freshwater Fish, 16, 133143 (2007)

5. L. R. Brown, P. B. Moyle, Environ. Biol. of Fish, 49, 271-291 (1997)

6. R. Kulmatov, A. Taylakov, S. Khasanov, Environmental Science and Pollution Research, 1-11 (2021)

7. Ö. Emiroğlu, A. S. Tarkan, N. Top, S. Başkurt, Ş. Sülün, Turkish Journal of Fisheries and Aquatic Sciences, 12, 925-936 (2012)

8. E. García-Berthou, Journal of Fish Biology, 71, 33-35 (2007)

9. R. E. Gozlan, J. R. Britton, I. G. Cowx, G. H. Copp, J. Fish. Biol., 76(4), 751-786 (2010)

10. J. Holčík, International Revue Gesamten Hydrobiologi, 65, 673-679 (1980)

11. G. K. Kamilov, Uzbekistan reservoir fishes, 234 (FAN press, Tashkent, 1975) (in Russian)

12. I. D. Leonardos, A. C. Tsikliras, V. Eleftheriou, Y. Cladas, I. Kagalou, R. Chortatou, O. Papigioti, Journal of Applied Ichthyology, 24, 213-217 (2008)

13. R. Liasko, A. Koulish, A. Pogrebniak, O. Papiggioti, L. Taranenko, I. Leonardos, Hydrobiologia, 658, 317-328 (2011)

14. A. P. Makeeva, Fish embryology, Publishing house of Moscow State University, 216 (1992) (in Russian)

15. G. V. Nikolsky, Fishes of the Amur River basin, 551 (Nauka press, Moscow, 1958)

16. I. Paschos, C. Nathanailides, M. Tsoumani, C. Perdicaris, E. Gouva, I. Leonardos, Belgian Journal of Zoology, 134, 55-60 (2004)

17. Fishes of Kazakhstan - Cyprinids, 3, 304 (Nauka press, Alma-Ata, 1988) (in Russian)

18. S. T. Ross, Environmental Biology of Fishes, 30, 359-365 (1999)

19. T. V. Salikhov, B. G. Kamilov, A. K. Atadjanov, Fishes of Uzbekistan, 152 (ChinorEnk press, Tashkent, 2001) (in Russian)

20. A. S. Tarkan, G. H. Copp, N. Top, N. Özdemir, B. Önsoy, G. Bilge, H. Filiz, Fisheries Management and Ecology, 19, 178-936 (2012)

21. M. Vetemaa, R. Eschbaum, A. Albert, T. Saat, Journal of Applied Ichthyology, 21, 287-291 (2005)

22. R. Yonekura, Y. Kohmatsu, M. Yuma, Biol. J. the Linnean Soci., 9, 601-610 (2007)

23. J. Zimmerman, B. Vondracek, Canadian J. Fish. and Aquatic Sci., 63, 1526-1535 (2006) 